\title{
Gender and climate change in the Indian Himalayas: global threats, local vulnerabilities, and livelihood diversification at the Nanda Devi Biosphere Reserve
}

\author{
M. V. Ogra ${ }^{1}$ and R. Badola ${ }^{2}$ \\ ${ }^{1}$ Department of Environmental Studies, Gettysburg College, Box 2455, 300 N. Washington Street, \\ Gettysburg, PA 17325, USA \\ ${ }^{2}$ Department of Ecodevelopment Planning and Participatory Management, Wildlife Institute of India, \\ Chandrabani, 248001 Dehra Dun, Uttarakhand, India
}

Correspondence to: M. Ogra (mogra@gettysburg.edu), R. Badola (ruchi@wii.gov.in)

Received: 19 September 2014 - Published in Earth Syst. Dynam. Discuss.: 11 November 2014

Revised: 19 March 2015 - Accepted: 10 June 2015 - Published: 7 August 2015

\begin{abstract}
Global climate change has numerous implications for members of mountain communities who feel the impacts in both physical and social dimensions. In the western Himalayas of India, a majority of residents maintain a livelihood strategy that includes a combination of subsistence or small-scale agriculture, livestock rearing, seasonal or long-term migration, and localized natural resource extraction. While warming temperatures, irregular patterns of precipitation and snowmelt, and changing biological systems present challenges to the viability of these traditional livelihood portfolios in general, we find that climate change is also undermining local communities' livelihood assets in gender-specific ways. In this paper, we present a case study from the Nanda Devi Biosphere Reserve (Uttarakhand, India) that both outlines the implications of climate change for women farmers in the area and highlights the potential for ecotourism (as a form of livelihood diversification) to strengthen both key livelihood assets of women and local communities' adaptive capacity more broadly. The paper intentionally employs a categorical focus on women but also addresses issues of inter-group and gender diversity. With this special issue in mind, suggestions for related research are proposed for consideration by climate scientists and social systems and/or policy modelers seeking to support gender justice through socially transformative perspectives and frameworks.
\end{abstract}

\section{Women, gender, and climate change}

It is increasingly evident that women are at the center of the climate change challenge. Women are disproportionately affected by climate change impacts, such as droughts, floods, and other extreme weather events, but they also have a critical role in combatting climate change (UNFCCC, "Gender and Climate Change" homepage; UN, 2014a).

It is by now widely accepted that we need both adaptation and mitigation measures to deal with the environmental changes already occurring and predicted to occur with a steadily warming planet (e.g., fluctuation and distribu- tions of annual mean temperature and precipitation, glacial melt, ocean acidification, sea level rise, storm surges, monsoon variations, ecological changes including biodiversity loss, among other direct effects). The 2009 Copenhagen Accord has already acknowledged the dangers for global mean temperature rise above $2{ }^{\circ} \mathrm{C}$, noting the particularly urgent threat for small island nations and coastal regions in terms of heightened vulnerability to both short- and long-term impacts of sea-level rise (UN, 2009). Meanwhile, at the socalled third pole of the Earth, there is a growing realization that environmental changes in the Himalayan mountains the water tower of Asia - threaten to undermine the security and well-being of a South Asian population of at least 1.6 billion people, including $40 \%$ of the world's poor (Rasul, 
2014). Yet in spite of the 1979 passage of the United Nations' Convention of Elimination of all Forms of Discrimination Against Women (CEDAW) and numerous declarations of the critical and important roles for women in promoting environmental sustainability (including by the Secretariat of the United Nations Framework Convention on Climate Change (UNFCCC), above), some development scholars and practitioners are still lamenting the gap between rhetoric and action in mainstreaming gender into climate change discussions, policy negotiations, and adaptation and/or mitigation practice. Four decades after the passage of CEDAW and nearly 20 years after the formation of the UNFCCC for example, Hemmati and Rohr observed that gender equality is "finally beginning to be accepted as one of the core principles of mitigating climate change and adapting to its impacts" (2009: 25).

Two special issues of the international journal Gender and Development (in 2002 and 2009, respectively) have helped to provide seminal reference points and analyses of the core issues, framing a rich discourse about gender and climate that includes academic researchers, policymakers, donor agencies, governments, NGOs, and activists from civil society (Masika, 2002; Denton, 2002; Nelson et al., 2002; Dankelman, 2002; Lambrou and Piana, 2006; Brody et al., 2008; Terry, 2009; Seager, 2009a; Sweetman, 2009; Enarson and Chakraboti, 2009; Dankelman, 2010; Aguilar, 2010; MacGregor, 2010; Arora-Jonsson, 2011; Alston and Whittenbury, 2012; Sultana, 2014; WHO, 2014). Contributions made through robust transnational activist networks such as GenderCC and the Gender and Disaster Network also inform debates about gender and climate change issues. Participants in such networks have helped to popularize the rallying call for gender justice that activists made prominent in Bali at the 2007 meeting of the Conference of Parties to the UNFCCC (Terry, 2009). Together, this body of work demonstrates that many of the indirect impacts of climate change - e.g., increased salinization of coastal agricultural fields due to storm surge and sea level rise, drying streams, inland water scarcity and drought associated with fluctuating extremes of temperatures, disrupted growing seasons and poor harvests, and increased intensity of storms - pose critical risks for people's lives and livelihoods, and in ways that affect different groups in different ways. It reveals a growing consensus around the belief that climate change not only promises to disproportionately negatively impact the world's poor, but that it will likely "magnify existing patterns of inequality, including gender inequality" (UNDP, 2014).

Clearly, the intersections of climate change impacts, poverty, and gender-based inequalities are complex and warrant continued attention. As guests to $E S D$ and participants in the transdisciplinary 2013 workshop "Adaptation and Resilience in the Hindu-Kush-Himalayas" (held at the University of Hamburg, Germany), we seek to help readers better understand the links between these issues through a focus on women's experiences with climate change at the Nanda
Devi Biosphere Reserve (NDBR), Uttarakhand, India. In contributing details from this part of the Himalayas to a broader cross-cultural literature that documents local experiences with climate change, we also aim to complement the quantitative, model-based approaches presented elsewhere in this special issue with perspectives from the ground. We hope that such an approach will help to deepen other people's understandings of the lived experiences in remote mountain communities dealing with a rapidly changing physical environment.

This paper is organized as follows: in the next section, we present a conceptual framework for the paper that emphasizes theories of differentiated vulnerability and relevance of the Sustainable Livelihoods (SL) framework (DFID, 1999) for analysis of adaptive capacity. We then discuss methodological issues, explaining our focus on women and outlining the physical and cultural context for the paper's central case study. Through our case study, we document some of the ways in which NDBR community members report currently experiencing and responding to climate change, and suggest how differentiated impacts can be viewed through a gender lens. Applying the SL framework to the example of livelihood diversification through ecotourism around the NDBR, we find that a homestay-based model emerging in NDBR is creating conditions for participating women to feel in greater control of their incomes and to more broadly engage in community-level development issues, which in turn delivers benefits for their larger communities. This part of our analysis shows that while some of women's livelihood assets are being undermined by climate change, such experiments with ecotourism are also strengthening assets in meaningful and specific ways. Our discussion emphasizes the types of assets that this model of ecotourism has enhanced for NDBR women, while at the same time explaining the benefits for the larger community. Yet, we also suggest that because overall household asset mix shapes livelihood outcomes, risks of capture of benefits by economic elites is a key concern. Ultimately, we use the example of women's experiences with ecotourism to demonstrate the value of an assets-based approach for improved understanding of gender-differentiated aspects of climate change more broadly. We close the paper with examples of ways that climate adaptation practice and policy can move from gender-blind to socially transformative, gender justice approaches and pose related research ideas for consideration by climate science and adaptation policy modelers, in particular. We also reflect on the methodological contributions that social scientists are especially well positioned to offer. Ultimately, we hold that examinations of gender-differentiated experiences related to climate change are important not only for what they may reveal about vulnerabilities and strengths, but that such examinations are also valuable in terms of illuminating the deeply personal scales at which the impacts of climate change will continue to be experienced. 


\section{Conceptual framework: differentiated vulnerability, sustainable livelihoods, and adaptive capacity}

Climate change has important direct and indirect effects that are not always immediately evident. At every scale, both between and within nations, social factors are critical in determining sources of strength and vulnerability to the impacts of climate change. Investigations of key relationships between differentiated vulnerability and risk in the context of natural disasters and catastrophic events offer important insights for studies of climate change (Enarson and Morrow, 1998; Poumadére et al., 2005; Neumayer and Plümper, 2007; Enarson and Chakrabarti, 2009; Mearns and Norton, 2010; Dankleman, 2010; Huang et al., 2010; David and Enarson, 2012; Seager, 2012; Sultana, 2014; Alagan and Aladukwaka, 2014; GDN, 2014; see also Blaikie and Brookfield, 1987; Ives and Messerli, 1989; Wisner et al., 2004). Taken together, these analyses of the loss of life, livelihood, and security associated with specific extreme weather events around the world demonstrate a range of differentiated and distinct impacts, intersecting along multiple lines including gender, race, age, ethnicity, class, and ability. This work demonstrates that most often, the factors contributing to vulnerability are interlinked and compound insecurity. In the Indian Himalayas, for example, many of the victims of deadly flash floods in 2013 near Kedarnath, Uttarakhand, were from a single village nearby, where - in a high-risk livelihood strategy employed by very poor mountain communities - a collective of men drawn from each household reportedly set out to collect medicinal forest products in the flood zone and never returned (field interview, May 2014; see also news reports by Pand, 2013, and Gusain and Datt, 2013). In this case, the mens' poverty, ethnicity, and gender conspired to create a heightened - and discriminatory - vulnerability that is literally embodied by the victims' social and economic status. Women's vulnerabilities are often also experienced through their physical bodies in similarly gender- and class-differentiated ways: for example, intensified exposure of poor or physically isolated women and girls to criminal predators (sexual and physical assault, rape, and human trafficking) has been documented crossculturally in the immediate aftermath of disaster events such as hurricanes and floods (Enarson and Chakraboti, 2009; David and Enarson, 2012; Kapoor, 2011; Aguilar, 2010).

Building on such insights from recent gender and disaster research (rapid-onset events), we can expect that slow-onset events associated with global and regional climate change will also yield differentiated impacts. But what such impacts are likely? And what enables or constrains people's capacity to best cope with these changes? The ability to successfully mitigate the impact of anticipated events or adapt to change over the long term will clearly depend on the ability to overcome vulnerability, whether at individual or collective scales. Therefore, it will be essential to find ways to promote meaningful and sustainable livelihoods for all - as well as to promote the economic security and political voice required to maintain the livelihood base. As this article demonstrates through its central case study, this is an especially salient issue for women who even between wealth and ethnic groups meet livelihood challenges with different sets of resources (or, as we refer to them in the paper, livelihood assets) than the men with whom they share households.

\subsection{Sustainable livelihoods and adaptive capacity}

Below, we present ways in which the Sustainable Livelihood (SL) framework (DFID, 1999) offers a robust base around which to further a discussion of differentiated vulnerabilities, adaptation and adaptive capacity, and mitigation of the livelihood-related impact of climate change. As shown in Fig. 1 and discussed further below, the SL framework is designed to offer "a way of thinking about livelihoods that helps order complexity and makes clear the many factors that affect livelihoods" (DFID 1999: 2). Application of the SL framework enables an examination of how different groups of people manage and combine varying livelihood assets available to them, and illustrates the varying influences of the institutions, policies and structures existing around them. Recognizing that the component parts of any cultural-economic system are never fixed in time or space, we find that the framework is best viewed as a conceptual model, representational of and adaptable to mutable local contexts.

In mountain regions such as those found in the Indian Himalaya, where local livelihoods are highly vulnerable to failure due to the ecological shocks and uncertainties associated with climate change, adaptation must be considered to be a fundamental response option. An adaptation-based approach aims at moderating the adverse effects of climate change through a wide variety of actions and adjustments in ecological, social, or economic systems and seeks to create benefits from opportunities associated with climate change (Fussel and Klein, 2006; Ellis 2000). An optimistic perspective suggests that one opportunity presents itself in the form of increased intensity of attention about the seriousness of the issue and potential flow of supporting resources to the region (i.e., as part of adaptation and mitigation response by the international community and the Indian government). Because adaptation has multiple and interlinked dimensions, adaptive capacity of local communities is governed both by internal, culturally specific characteristics as well as by larger external social, economic, and political structures that empower or constrain action. In our view, capacity building in adaptation is also predicated on the privilege of choice: a community, household, or person who lacks choice or alternatives in any situation has no real power. Thus, strengthening the adaptive capacity at any scale by expanding the range of response options is central to the challenge of addressing local vulnerabilities to the impacts of climate change, and to the goal of empowering people to be able to make meaningful and viable choices about adaptation itself. 


\section{Sustainable Livelihoods (SL) Framework}

a)

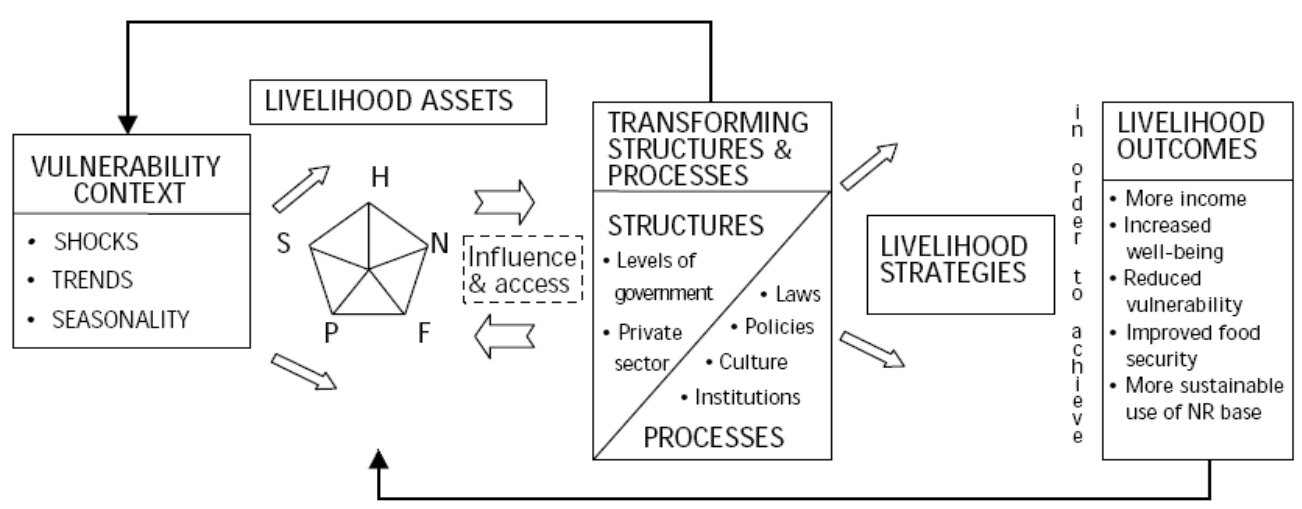

(DFID, 1999)

b)

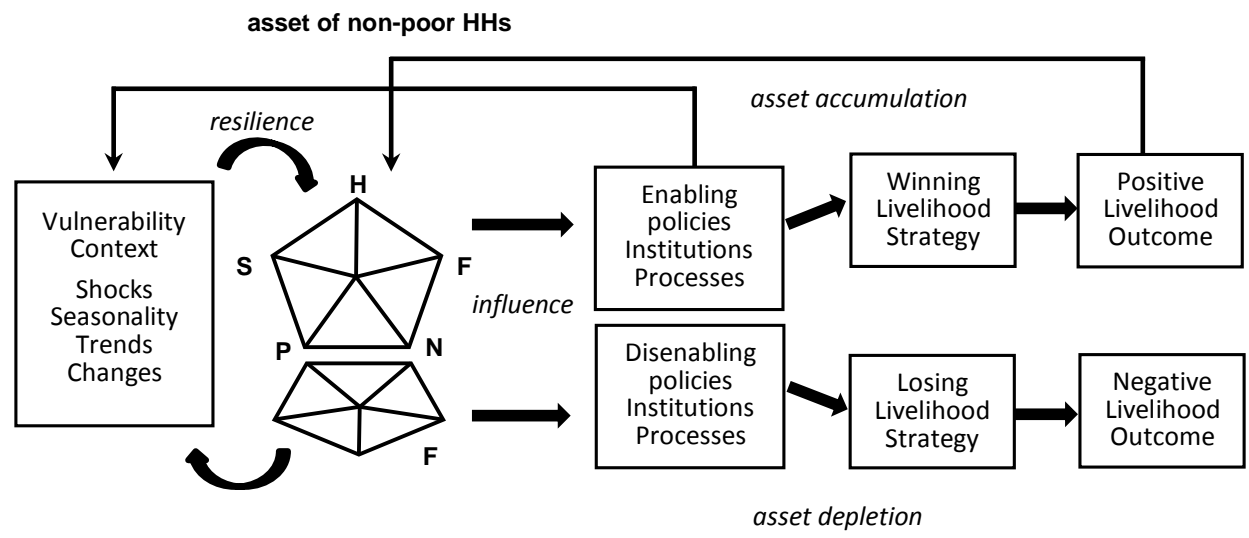

asset of poor HHs

(FAO, 2005)

Figure 1. (a) Basic model (DFID, 1999), where $\mathrm{H}$ is human capital, $\mathrm{N}$ is natural capital, $\mathrm{F}$ is financial capital, $\mathrm{P}$ is physical capital, $\mathrm{S}$ is social capital. (b) Illustration of assets balance for poor vs. nonpoor households as suggested by FAO (2005), where assets above are shown in reference to enabling and/or disenabling transformative structures and processes (policies, institutions, and processes).

One important way to increase adaptive capacity is to support initiatives which strengthen people's combined set of livelihood capital assets (i.e., the arrangements of natural, financial, physical, human, and social forms of capital illustrated in Fig. 1). While the mainstream climate change discourse gives much attention to macro-scale, transformative structures and processes (international carbon markets, green energy infrastructure, expansion of hydropower grid, etc.), attention also needs to be paid in understanding the microscale factors that determine the lived experience of climate change. Asset analysis, in particular, needs to be achieved through the lens of differentiation in order to achieve a finerscale understanding of threats and opportunities (see Fig. 1b which highlights the assets profile for generalized poor versus non-poor households). As suggested in Table 1, which provides examples of the five categories of livelihood assets with special reference to women's position in the Indian Himalayas, a gendered perspective on assets adds value even in the context of less well documented intra-group differences within economic or cultural groups. Worldwide, many women live under conditions of exclusion or vulnerability strictly because of their gender, with limited access to key assets such as land and other productive resources, knowledge, technology, power, decision-making, education, healthcare, and food (Aguilar, 2010). A baseline understanding of gender-differentiated livelihoods assets is therefore essential to planning for adaptation, even in seemingly homogeneous communities. When adaptive capacity is understood in the context of mapped assets from this perspective, we believe that a more holistic approach to planning can follow. 
Table 1. Livelihood assets profile in Uttarakhand Himalaya, with special reference to women's assets.

\begin{tabular}{|c|c|}
\hline Human capital & $\begin{array}{l}\text { - Sex ratio favors males, suggesting lower status of women and girls. Ultrasound technology since } \\
2001 \text { has coincided with a significant drop in the sex ratio for children. }{ }^{\text {a,d }} \\
\text { - Literacy rates favor men, suggesting lower status of women }{ }^{b}\end{array}$ \\
\hline Natural capital & $\begin{array}{l}\text { - Land tenure associated with men. Few women with land title }{ }^{\mathrm{c}} \text {. } \\
\text { - Traditional crops dominated the agricultural land until } 1975 \text { but cultivation of cash crops cur- } \\
\text { rently dominate agricultural land. This leads to narrowing of livelihood resource base as cash } \\
\text { crops replace traditional crops. Related to food security and erosion and/or loss of traditional agri- } \\
\text { cultural knowledge held by women. } \\
\text { - Presently only } 42 \% \text { of people are cultivating some traditional varieties of crops. These did not } \\
\text { bring in a lot of cash revenue for the household and as a result provided food security particularly } \\
\text { for women and children. } \\
\text { - Development activities and climate change resulting in shrinking forest and agricultural lands } \\
\text { and changing cropping patterns means that women have to travel more for fuelwood and fodder. } \\
\text { The households' dependence is now on food material procured from the market, often low-quality } \\
\text { food coming from the plain areas. }\end{array}$ \\
\hline Financial capital & $\begin{array}{l}\text { - Cash flows controlled by men } \\
\text { - Access to credit and collateral favors men. Although several schemes for women have been } \\
\text { launched, most women are not aware of them. }\end{array}$ \\
\hline Physical capital & $\begin{array}{l}\text { - Roads, built environment, technological interventions are directed to men's articulated priori- } \\
\text { ties. Men are more likely to get employment in the development activities going on in the region. } \\
\text { Roads help men to commute and travel, and reflect their priorities for destinations. } \\
\text { - Machines for de-husking were given to women but these were too heavy and are useless. } \\
\text { (Women not involved in machine design) }\end{array}$ \\
\hline Social capital & $\begin{array}{l}\text { - Institutional networks favor men and presume male heads of household (e.g., Panchayati Raj), } \\
\text { despite quotas for women's participation. Even if women are members they do not speak up in } \\
\text { such meetings due to their minority presence as well as social and cultural taboos. The place and } \\
\text { time of meetings often does not suit women. } \\
\text { - Women's organization not empowered to make any major decisions, their decisions are related } \\
\text { to cleanliness drives or some other minor social activities. Where cash is involved, men make the } \\
\text { decisions. }\end{array}$ \\
\hline
\end{tabular}

${ }^{\mathrm{a}}$ In 2001 all-India sex ratio $(\mathrm{F} / \mathrm{M})$ for children $=927 / 1000$ and for adults $(\mathrm{F} / \mathrm{M}) 933 / 1000$. In 2001 Uttarakhand sex ratio $(\mathrm{F} / \mathrm{M})$ for

children $=908 / 1000$ for adults 962 / 1000 (GOI, 2002). In 2011, the all-India sex ratio $(F / M)=919 / 1000$ for children and $943 / 1000$ for adult. In 2011, Uttarakhand sex ratio $(\mathrm{F} / \mathrm{M})=$ livelihood diversification 890 / 1000 for children; 963 / 1000 for adult (GOI 2011). In Chamoli district, our field data indicate a decrease in child sex ratio $(\mathrm{F} / \mathrm{M})$ from $935 / 1000$ in 2001 to $889 / 1000$ in 2011

b In 2011, the all-India literacy rate $=65.46 \%$ (female) and $82.14 \%$ (male). In 2011, Uttarakhand literacy rate $=70.01 \%$ (female) and $87.4 \%$ (male) (GOI,

2011). In Chamoli district, our field surveys suggest 2011 literacy rates of $72.32 \%$ female and $93.4 \%$ male.

${ }^{\mathrm{c}}$ In 2011, female agricultural workforce was $70 \%$, yet only $9.5 \%$ own land (FAO data cited in Kapoor 2011).

The extent to which ecosystems and communities are vulnerable or resilient depends both on exposure to changes in climate and physical changes as well as on the ability of the impacted social system to adapt. In applying the SL framework to rural communities at risk of livelihood failure in a more general sense (i.e., not solely related to climate change), we consider three broad clusters of livelihood strategies for the rural communities that have already been identified and can be applied in context of the Indian Himalayas. These are agricultural intensification and/or extensification, migration, and livelihood diversification (Scoones, 1998). Given existing livelihood challenges related to larger patterns of rural poverty and the regional physical geography (e.g., steep slopes, flash flooding, landslides), agricultural expansion is not a viable long-term solution for most rural households. Agricultural intensification is already in place where households have sufficiently strong assets. Migration, similarly, is a strategy already in place throughout the region due to underlying pressures of livelihood insecurity. In addition to supplementing rural household incomes, remittances may provide additional social benefits that enhance overall assets and sense of empowerment to households as well. For example, researchers in Nepal have observed that Dalit migrants benefitted from upward social mobility through their increased income and ability to purchase land (Adhikari and Hobley, 2011). Others have found that some groups of women left behind by male out-migrants from the hills of Nepal were able to participate more effectively in community-based forestry initiatives and benefitted from their status as de facto heads of household (Giri and Darnhofer, 2010). At the same time, migration must also be considered in terms of the social and emotional costs. 
Writing about loss of place associated with climate changeinduced migration, Adger et al. (2013) note that migration under such circumstances can be maladaptive for some, because of the hardship associated with the severing of placebased attachments. Thus, livelihood diversification is perhaps not surprisingly the most prevalent strategy adopted by area residents. As discussed in the next section, diversification in the site includes niche marketing of the unique cultural heritage and ecological features of the NDBR.

\section{Materials and methods}

As described below, our discussion of the genderdifferentiated impacts of climate change and related case study of livelihood diversification at NDBR focuses on the experiences of women. In this section, we further explain this focus, introduce the paper's related research questions, and outline our data sources.

\subsection{Focus on women: why women's experiences still matter}

As already discussed, analysis of climate change impacts and adaptation strategies will be enhanced through differentiated lenses of understanding. Worldwide, poor and marginalized populations already disproportionately experience the negative impacts of climate change (Mearns and Norton, 2010). It has also been argued that within poor and marginalized groups, women often experience more severe forms of poverty relative to men, due to underlying gender inequalities (Demetriades and Esplen, 2010). Discussing health impacts of climate change in the Hindu Kush Himalayan region specifically, Eriksson et al. (2008: 14) similarly observe that while mountain communities and ethnic minorities are already socially marginalized, within these groups women, the elderly, children, and the disabled are the most vulnerable and as such, "will suffer the most from the impacts of climate change because they often have less resources to fall back upon."

At the same time, we recognize that women do not comprise a homogenous group, and we do not suggest here that gender-differentiated impacts fail to apply to men (or members of other gender groups). For example, differences in overall economic status between poor and non-poor households often overshadow gender differences such that elite women have more in common with men of their own socioeconomic group than with women of different caste and/or class-based or occupational groups (Agarwal, 1992; Rocheleau et al., 1996). Age and marital status, as we have ourselves argued elsewhere (Badola et al., 2014b) are similarly intersecting categories that may overshadow gender differences between economic groups. However, while economic security and caste and/or class may reinforce elite privilege at the individual scale, perpetuation of gender-based inequities within households nevertheless works to undermine women's collective strategic interests (Moser, 1989). Many measures of gender-based forms of violence, economic inequality, and other forms of deprivation and disparity have been shown to overwhelmingly negatively affect women as a group (Seager, 2009b). Culturally embedded and institutionalized forms of inequality such as denial of opportunities to healthcare and education, persistence of economic and political discrimination, and continued assaults on women's personal safety through sexual violence (to name a few issues) are indeed "sticky" obstacles, as phrased by the authors of the 2012 edition of the World Development Report (World Bank, 2012), and which together help to explain why women's issues, in particular, are still central to gender and climate change frameworks. Echoing this idea, the UNFCCC has noted the critical link between women's empowerment and climate change adaptation, claiming that the empowerment of women "will be a significant factor in meeting the climate challenge and achieving the long-term objectives of the Convention" (UN, 2014b). Situating her own analytical focus on women in the area of gender and climate change, Dankelman reminds us that all over the world gender relations are characterized by "asymmetry of power between women and men as a pervasive trait" (2010: 11). Problematizing the connections between women's experiences, gender-based inequities leading to differentiated vulnerabilities, and risks associated with climate change therefore presents a critical opportunity to prioritize, galvanize support around, and ultimately address the long-term and "sticky" issues noted above.

Yet as development scholars Harcourt and Escobar observed in 2005, "Too often the differences between women and men become smoothed away in progressive analytical frameworks. Knowledge about women continues to be the hardest to come by" (quoted in Dankelman, 2010: 11). In seeming agreement, Aguilar (2010) outlines three areas of knowledge within studies of climate change impacts that she believes must be supported through research: (1) specific conditions that shape women's (and especially poor women's) vulnerability; (2) gender-specific risk assessment and management; and (3) gendered strategies for enhancing adaptive capacity. Thus, we follow Dankelman (2010) and Aguilar (2010) by maintaining a primary focus on threats and opportunities related to women's livelihoods, highlighting the role of factors such as wealth and ethnicity where we are able to do so. We employ this approach to make visible the experiences of resident women that might otherwise be sidelined, and in the process seek to contribute to the body of related and regional literature. Responding to the political urgency of keeping women as a group methodologically and conceptually foregrounded, even as we recognize gender as a socially constructed category, ${ }^{1}$ our central questions in this paper are as follows:

\footnotetext{
${ }^{1}$ In this paper, we focus on primarily on one gender-based group (women). Though gender is often aligned with biological sex lines (male $/$ female $=$ men $/$ women $)$, we follow social scientists' con-
} 
- What are NDBR women's concerns about climate change, as related to current or potential impacts to their livelihood assets?

- How can livelihood diversification contribute to a strengthening of women's assets in the NDBR?

\subsection{Data sources}

To address the questions posed above, we draw upon both the conceptual frameworks described in Sect. 2 and our direct observations and interactions with women in the region. Many details reported in this paper are derived from fieldwork conducted in the context of a recent interdisciplinary study undertaken for the Wildlife Institute of India, "An Integrated Approach to Reduce the Vulnerability of Local Community to Environmental Degradation in the Western Himalayas, India" (Badola et al., 2014a). Among other goals, this larger project sought to develop an updated socioeconomic profile for the NDBR, document land-use patterns and pressures, quantify key ecosystem functions of the reserve's forested landscapes, and identify possible strategies for sustainable livelihoods. Over a 2-year period (20122014), members of a WII research team surveyed households of 22 randomly selected NDBR buffer zone villages about these topics $(n=764)$. Respondent households were selected through a stratified random sampling approach that sought to include residents of different gender, ethnicity, age, wealth, occupational and locational categories. Against this backdrop, we were able to concurrently collect additional qualitative data in the form of perceptions about climate change and ecotourism as an emergent, alternative livelihood strategy. For this part of the study, our methods emphasized direct observation, key informant interviews, informal discussions, and household-level and women-only group discussions. The resulting qualitative information was grouped and hand-coded thematically, then analyzed in terms of the differentiated vulnerability and SL frameworks discussed above.

\section{Study area}

The NDBR is a representative wilderness area in the western Himalayas, experiencing climate-induced pressures to both its physical and social systems. It is perhaps best well known for its role in protecting the world's fourth-highest mountain, Nanda Devi Peak (elev. 7817 m), and constitutes an important reservoir of water in the form of glacial ice and snow, forests, and high-altitude biodiversity. Development activities, such as the construction of roads as well as several hydroelectric projects, have rapidly increased in the region.

ceptualization of gender as a fluid, non-binary, changeable, and culturally constructed form of identity that varies over time and space.

\subsection{Physical setting}

The Nanda Devi Biosphere Reserve (NDBR) is located between $300.05^{\prime}-310.02^{\prime} \mathrm{N}$ latitude and $790.12^{\prime}-800.19^{\prime} \mathrm{E}$ longitude, situated in the biogeographical zone of $2 \mathrm{~B}$ (Rodgers and Panwar, 1988). The reserve has a wide altitudinal range from 1800 to $7817 \mathrm{~m}$. and presently covers an area of $5860.69 \mathrm{~km}^{2}$, spread over Chamoli district (in Garhwal division) and Bageshwar and Pithoragarh districts (in Kumaon division) of Uttarakhand state. The basin is dominated by the Nanda Devi mountain, India's second highest peak (NDBR, 2002) and revered locally as a symbol of the Hindu goddess, Nanda (Kala and Maihkuri, 2011). The basin is also the headwater of several rivers such as Gori Ganga, Rishi Ganga, Dhauli Ganga, and Girthi Ganga which forms the Alaknanda River of the Garhwal Himalayas. Pindari and Milam glaciers are important landmarks in the region. The entire area has historically remained snow bound for more than 6 months of the year, with reaches above $4500 \mathrm{~m}$ a.s.l. continually in snow (Khacher, 1978). More recent reports cite annual temperature ranges in the area between 0 and $24^{\circ} \mathrm{C}$, with average rainfall of $928.82 \mathrm{~mm}$ yr falling mainly during July and August monsoon (Kala and Maikhuri, 2011, citing 2002 figures). The area currently experiences three main seasons: winter (November to March), with heavy snowfall in the months of December, January, and February; summer (April to midJune) and rainy season (mid-June to September). Most of the flora and fauna protected in the reserve are native and endemic, and the reserve has long held species with conservation significance across taxonomic categories. Notable animals include the snow leopard (Panthera uncia), Asiatic black bear (Ursus thibetanus), Himalayan brown bear (Ursus arctos), Himalayan musk deer (Moschus chrysogaster), bharal (Pseudois nayaur), and Himalayan tahr (Hemitragus jemlahicus).

In recognition of the intrinsic value and uniqueness of the area, in 1988 the United Nations (UNESCO) designated the Nanda Devi National Park as a World Heritage Site. The larger biosphere reserve today includes the Nanda Devi Sanctuary (declared by the Government of India in 1939), the Nanda Devi National Park (declared in 1982), and the Valley of Flowers National Park (incorporated into the core zone of NDBR in 2000) (Green, 1993; NDBR, 2002).

\subsection{Local communities}

Zonation and human use categories at NDBR are based on the United Nation's Man and Biosphere (MAB) reserve concept of balancing basic human welfare and with environmental protection through a zonation approach. The biosphere reserve is comprised of two core areas (the Nanda Devi National Park and Valley of Flowers National Park, respectively), a buffer zone (47 villages), and a transition zone. The core zones of the reserve are free from human settlement and have remained largely undisturbed due to inaccessibility and 
Table 2. Socio-economic profile of NDBR households. ${ }^{1}$

\begin{tabular}{ll}
\hline Characteristic & Frequency $(n=764)$ \\
\hline Women & $44.6 \%$ \\
Men & $55.4 \%$ \\
Married & $79.6 \%$ \\
Bhotiya & $33.9 \%$ \\
Garhwali & $66.1 \%$ \\
Average HH size of respondent & 5.5 members \\
Average age of respondent & 45.8 years \\
Respondents with education of more than 10 years & $19.2 \%$ \\
Respondents with education of 10 years & $20.0 \%$ \\
Respondents with education of 5 years or less & $24.3 \%$ \\
Electrified households & $80 \%$ \\
Mean annual household income, including & INR 95646.4 \pm 3332.4 \\
contributions of forest-derived products & (approx. USD 1524) \\
Mean annual household income, without & INR 80712.7 \pm 3301.4 \\
contributions of forest-derived products & (approx. USD 1287) \\
Landholding size & $0.40 \pm 0.01$ ha per household \\
& (range: 0.0-5.16 ha per household) \\
\hline
\end{tabular}

\footnotetext{
${ }^{1}$ Source: WII study report (Badola et al., 2014a)

${ }^{2}$ At time of writing, USD $1=$ INR 62.7
}

Table 3. NDBR household member occupations (reported for all members of surveyed households).*

\begin{tabular}{ll}
\hline Occupation & $\begin{array}{l}\% \text { of total } \\
(n=2134)\end{array}$ \\
\hline Agriculture (including horticulture) & 59.8 \\
Floriculture & 10.9 \\
Government job & 7.3 \\
Beekeeping & 6.7 \\
$\begin{array}{l}\text { Dairy production } \\
\text { Private sector employment } \\
\text { (mainly tourism-related) }\end{array}$ & 4.6 \\
$\begin{array}{l}\text { Other livestock rearing } \\
\text { (goats, sheep, mules, ponies) }\end{array}$ & 3.7 \\
$\begin{array}{l}\text { Other sources of income } \\
\text { (includes handicrafts production }\end{array}$ & 0.8 \\
and daily wage labor) & 6.2 \\
\hline
\end{tabular}

* Source: WII study report (Badola et al., 2014a)

protections from human interference afforded by the national park designations. The NDBR buffer zone encompasses areas distributed over the Chamoli, Bageshwar, and Pithoragarh districts. Lata and Reni villages remain among the best known settlements in this region due to their central role and involvement in the Chipko forest preservation movement of the 1970s-1980s and their proximity to desirable trekking route start points. The nearby town of Joshimath is a regional transportation hub that provides the surrounding upland villages with secondary school, hospital, and market facilities. Joshimath also serves as a base for religious pilgrims and other tourists, with state-sponsored and privately run facilities for dining, lodging, and transportation.

The dominant ethnic and religious communities residing within the NDBR are represented by the indigenous Bhotiya community and the Garhwali pahari (literally, "of the mountain") Hindu communities. Traditional livelihood strategies of the Bhotiya tribe were historically based on transhumance and seasonal migration to Tibet associated with long-distance trade, but trans-border trade ended in the 1960s due to conflict between India and China. Bhotiyas also suffered hardship in this period from loss of their winter settlements under the Zamindari Abolition and Land Reform Act of 1960 (Kala and Maikhuri, 2011). Throughout the NDBR, villagers in both groups are today dependent on a harsh and often remote environment which limits livelihood strategies to a relatively small range of forest- and agriculturally based options (Tables 2-3). Families mainly practice rain-fed tree crop mixed farming similar to other parts of the central and northwest Himalayas, cultivate terraced fields for marginal subsistence agriculture and limited cash cropping, and rear cattle and sheep for milk. Supplemental income-generation practices such as beekeeping, floriculture, and the cultivation and collection of medicinal plants are in practice, but not as widespread as in the past. Bhotiya communities also practice a traditional craft of weaving, raising sheep for wool as well as meat. Other sources of income include wage labor and short-term employment associated with the 2005 National Rural Employment Guarantee Act (NREGA) and sale of land for hydroelectric or other infrastructure projects. While we do not have sufficient data to report frequency of male out-migration and associated remittances, key infor- 
mants reported to us that this is also an important aspect of contemporary household income generation. Yet emigration of household members also carries a cost: as one informant casually commented, "Everyone wants to go, but not all have the money for it."

Most importantly for villages located near road and trekking route heads, adventure and nature tourism has been an important source of income through local employment of NDBR residents as porters, trekking guides, cooks, hotel workers, and drivers since the opening up of routes to the Nanda Devi peak in the 1930s (Kala and Maikhuri, 2011; Von Hedemann 2010). Trek guiding is a particularly important occupation, albeit practiced by only a minority of residents today for whom the income can be substantial: in one analysis of NDBR guides' self-reported income, annual earnings ranged from INR 7000 to INR 78000 (Von Hedemann, 2010). Gifts from adventure tourists also comprise a minor but socially important resource (Maikhuri et al., 2001). However, the closure of the core zone to tourists and trekking expeditions in 1982 caused significant hardship; in some communities over $90 \%$ of youths were employed as porters and guides (Kala and Maikhuri, 2011). Religious tourism associated with shrines in the area have also long been economically important to the regional economy, with pilgrims representing $60 \%$ of the total tourists in the Uttarakhand Himalaya by some accounts (Kala and Maikhuri, 2011).

Continued demand for nature-based tourism throughout the area and a desire to derive additional benefits from biodiversity conservation has led to the promotion of ecotourism in some of the NDBR buffer zone villages. In the earlier tourism models in this area, the males were largely employed as porters and guides to accompany trekking parties leading to their absence for long periods of time. This resulted in additional burden of domestic and agricultural work on the women, without recognition of or compensation for their labor. It also led to employment for only a small number of people, mostly men with access to the main tourism nodes and who were directly employed in such activities. More recently, a culturally linked, homestay-based form of ecotourism is currently being promoted by residents of several villages within the NDBR. Such village-based ecotourism generates significant income for participating households and remunerates the labor contributions made by the entire family. According to a 2010 study of self-reported homestay operator incomes in the buffer zone villages of Tolma, Lata, and Urgam, most of their guests are international nature tourists who pay approximately INR 300 per day and whose visits earn operators an average annual homestaybased income that ranges from INR 490 to INR 141750 (Von Hedemann, 2010). Self-reported estimates of the number of tourists per year in that study ranged from just 4 to as many as 500; removing outliers, the average for these areas in 2010 was 21 tourists per year, concentrated in the months of May-September (Von Hedemann, 2010). Thus, villagebased ecotourism provides an opportunity for NDBR resi- dents to supplement uncertain seasonal incomes and engage in the possibilities of both alternative development trajectories and strengthening of assets. This is particularly relevant for NDBR communities because the state-led development in the region has focused on transportation and hydropower infrastructure projects and failed to promote sustainable local livelihoods, while simultaneously creating additional threats to the site's rich natural and cultural resources.

As described by long-term NDBR researchers, "The sociocultural fabric is as interesting as the natural" (Kala and Maikhuri, 2011: 89). Both communities maintain rich traditions of song, dance, weaving and handloom arts, and linguistic and culinary traditions unique to the mountain environment. As in many Himalayan communities where women's labor is critical to household viability (Badola et al., 2014b), our observation is that Bhotiya and Garhwali women in the NDBR have both traditionally held (and continue to hold) a relatively high status and expect decision-making in the household to be a shared activity between members. At the same time, daily responsibilities and expectations appear to follow gender-based divisions of labor found throughout the region, where control of money and capital lie primarily with adult men (i.e., as recognized heads of household and wage earners) and adult women in the household have greater control over household resource allocation in day-today living. ${ }^{2}$ While agriculture is practiced widely by both men and women, men also seek work for wages. Women in the sites we visited were responsible for household food production and distribution, agricultural labor in the form of weeding and cultivation, weaving, sale of NTFPs (nontimber forest products) and milk, and collection of water, fuelwood, fodder, and domestic NTFPs. NTFP collection is not confined to women, however: The highest-value NTFP $O$. sinensis (a caterpillar whose cocoon hosts a fungus used in traditional Chinese medicine) is collected mainly by men, and comprises an important source of supplemental income. As shown in Table 1, larger patterns of asset distribution nevertheless place women (as a group) in a position of strategic disadvantage compared to men (as a group).

\section{Results: women, climate change, and livelihood diversification through ecotourism}

\subsection{Gendered dimensions of climate change in the NDBR}

Models seeking to understand the long-term effects and physical drivers of climate change in the Himalayas are discussed elsewhere in this issue, and suggest the depths, limits, and shifting terrain of our understanding. As we discuss further in this section, the meaning of these changes from a social perspective varies geographically and between groups

\footnotetext{
${ }^{2}$ As shown in Table 2, reported gender expression in the study area was also binary (women/men).
} 
of people, depending largely on the range of assets and capabilities available for coping and adaption. With Himalayan farmers already in a heightened position of vulnerability due to reliance on rain-fed agriculture and natural resources associated with the forests of the NDBR, it is important to understand how climate change may further impact members within a household. This holds both within households as well as between households that hold different markers of wealth. To give context and a sense for the range of interconnected impacts of climate change already being perceived at the local scale, in this section we summarize impacts reported and observed in the field. Figures 2 and 3 present these impacts in terms of differentiated vulnerabilities for women and related impacts on women's livelihood assets. Narrative highlights, below, help to give context and examples of these broad trends.

Residents readily spoke to us about livelihood-related losses that they perceived to be related directly to climate and/or weather. When we asked people to describe environmental changes that they had noticed over the past 1520 years, increased intensity of sun, warmer overall temperatures, unfamiliar rain and snow patterns, and reduced glacial extent ("Where it used to be snow, now we walk on land") were all cited as examples. However, while mixedgender groups agreed on problems facing their community and described changes in precipitation and temperature, women's responses emphasized their knowledge and direct experience as cultivators and laborers in their households' agricultural fields. Indeed, loss of generationally communicated, traditional environmental knowledge (e.g., about traditionally cultivated crops and related food preparation techniques, knowledge of identification and extraction techniques for important NTFPs such as edible and medicinal species) was specifically cited by women as an indirect yet important impact of climate change that warranted their concern. Women also reported specific impacts of climate variability and change such as more intense hail storms with much larger-sized pellets that damaged apple flowers, untimely frost that damaged rajma flowers, and increased fungal disease and unfamiliar insect pests in the grain crops that were believed to be caused specifically by unpredictable and late rains. Insect infestation was a recurring complaint. Reflecting dependence on monsoon-fed agriculture, the theme of late rains was prominent in all of our discussions of agroecological impact. Heavier rainfall was also believed to be the cause of an increase in weedy species in the fields.

Due to combined changes in hail, frost, rainfall, and cropraiding, the women we met with consistently reported that the resulting crop loss was contributing to local food insecurity and increased dependence on market-based but less nutritious varieties of vegetables and grains. According to these women, this contributes to reduced well-being for all members of the household. At the same time, our direct observations suggest that as food preparers for the family who prioritize the nutritional and caloric needs of others in the fam- ily, women's well-being in this regard is affected to a greater degree. This is particularly the case for poorer households, for which crop failure or loss from damages are more pronounced in impact.

In group interactions, some households also noted that unreliable harvest and uncertainty associated with rain had motivated them to shift away from agriculture and in favor of intensified animal husbandry, although increased crop-raiding (by monkeys, boars, porcupines, bears, and mice) was also sometimes a factor. Conversely, others told us that families are now reducing their total number of animals because of livestock predation problems associated with leopards and bears. Still, others took no action, as in the words of one woman: "We cannot do anything."

Changes in the availability of important NDBR resources such as water, medicinal plants, grass (for fodder) and fuelwood constituted another key indicator of a changing environment and reflected women's labor-based knowledge despite differences in ethnicity and wealth. We were told that that the extent and variety of trees has been decreasing and the height of native grasses has reduced. In describing the indirect effects, women pointed to drops in milk production in their cattle due to a lack of high-quality fodder species. Grassland and forest degradation was also a major concern, reported to not only increase the overall time and distance required for women to collect fuelwood and fodder, but also their increased risk and concerns of falling from rocky slopes. Some reported a decision to purchase fodder in response to declining supplies and increased personal risk; others suggested that the increased wildlife sightings in the forest and fear of attack by wild animals was similarly a motivation to purchase fuelwood.

Loss and degradation of land associated with flash floods and landslides was largely recognized as cloudburst damage and perceived to be beyond villagers' control ("Disaster is natural"). However, in areas where hydroelectric power construction activities constituted the dominant driver of local environmental change, women raised concerns about the exacerbating effect of frequent dynamite blasting and land clearing. Construction activity in such sites was perceived to increase vulnerability to landslides, drive local deforestation, and cause the drying up of local springs. Indiscriminate and unsustainable fuelwood cutting from nearby forests by migrant laborers was heavily blamed for both fuelwood shortages and forest degradation in particular.

A final set of concerns were reported in terms of intangible, but important indirect social impacts related to cooperation between women of different households. The change in timing of common tasks related to agricultural and forest work was believed to be responsible for fewer opportunities for women of different backgrounds and households to work together, and competition for limited natural resources is starting to contribute to intra-household stress. Moreover, women told us the younger generation aspires to move away from traditional livelihoods based on agriculture and use of 


\begin{tabular}{|c|c|c|c|c|}
\hline & Type of Change & Household-level Impacts & Impacts for Women as a group & Further Differentiated Impacts \\
\hline 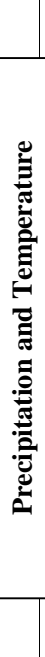 & $\begin{array}{l}\text { * Higher summer } \\
\text { temperatures } \\
\text { * Erratic monsoon and } \\
\text { more intense rains } \\
\text { * Flash floods and } \\
\text { landslides } \\
\text { * Earlier frost dates } \\
\text { * Rain instead of snow } \\
* \text { More intense } \\
\text { hailstorms }\end{array}$ & $\begin{array}{l}\text { * Crop loss/crop damage; } \\
\text { Lowered agricultural yields } \\
\text { due to unexpected timing } \\
\text { and intensities of heat, cold, } \\
\text { and precipitation } \\
\text { * Income loss in cash crop } \\
\text { cultivation } \\
\text { * Less food available for } \\
\text { subsistence cultivators } \\
\text { * Household food insecurity } \\
\text { * Diminished health status } \\
\text { for households }\end{array}$ & $\begin{array}{l}* \text { Women prepare food for all } \\
\text { household members but are } \\
\text { typically the last to eat; food } \\
\text { preparer also eats least of all } \\
\text { other household members } \\
\text { * Outmigration of sons and } \\
\text { husbands leads to stress and } \\
\text { hardship for women who } \\
\text { become the de facto heads of } \\
\text { household }\end{array}$ & $\begin{array}{l}\text { * Food scarcity issues related to climate change } \\
\text { occur in both Garhwali and Bhotiya families } \\
\text { (not observed as differentiated by ethnicity) } \\
\text { * Inequities related to food allocation and } \\
\text { distribution are a greater problem for women in } \\
\text { poorer and larger households, where food } \\
\text { scarcity issues are more prevalent } \\
\text { * There are important age-differentiated } \\
\text { impacts for women in both communities. } \\
\text { Younger women (daughter-in-laws) are } \\
\text { customarily the food preparers. Needs of older } \\
\text { women (mother-in-laws), men, and children are } \\
\text { all normally met before those of the food } \\
\text { preparers } \\
\text { * Male outmigration poses specific problems for } \\
\text { women of smaller households and households } \\
\text { without young men. Opportunity cost } \\
\text { associated with emigration of young males is } \\
\text { made up for by those left behind }\end{array}$ \\
\hline 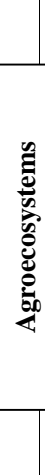 & $\begin{array}{l}\text { * Increase in weedy } \\
\text { plant species } \\
\text { * New insect pests, } \\
\text { including mosquitos } \\
\text { and new agricultural } \\
\text { crop pest species } \\
\text { * Increased conflict } \\
\text { with wildlife (attacks } \\
\text { on humans and } \\
\text { livestock; crop } \\
\text { predation) }\end{array}$ & $\begin{array}{l}\text { * Increased need for weeding } \\
\text { * Increased need for pesticide } \\
\text { purchase and field application } \\
\text { * Increased need to protect } \\
\text { fields and home from } \\
\text { wildlife } \\
\text { * Declining crop yields (see } \\
\text { above) } \\
\text { * Increased mosquito bites }\end{array}$ & $\begin{array}{l}* \text { While men are primarily } \\
\text { responsible for earning } \\
\text { wage-based income, women } \\
\text { are primarily responsible for } \\
\text { weeding fields. } \\
\text { * Women sell their labor as } \\
\text { workers through informal } \\
\text { networks in exchange for } \\
\text { payments 'in kind' (e.g., a } \\
\text { share of harvested } \\
\text { foodgrains or field-based } \\
\text { fodder), while men earn } \\
\text { wage labor through formal } \\
\text { markets and NREGA } \\
\text { schemes. }\end{array}$ & $\begin{array}{l}\text { * Gender-based division of labor pattern holds } \\
\text { both in Garhwali and Bhotiya households (not } \\
\text { observed as differentiated by ethnicity) } \\
\text { * Women of poorer households experience } \\
\text { greater exposure to harsh field conditions than } \\
\text { women in wealthier households (wealthier } \\
\text { households hire laborers to assist in cultivation- } \\
\text { related tasks, while members of poorer } \\
\text { households work as laborers) }\end{array}$ \\
\hline 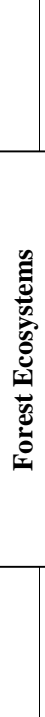 & $\begin{array}{l}* \text { Drying waterways } \\
\text { and forest springs; } \\
\text { reduced streamflow } \\
\text { * Changes in } \\
\text { vegetation and plant } \\
\text { regeneration rates, } \\
\text { including increase in } \\
\text { invasive/weedy } \\
\text { species } \\
\text { * Reduction in } \\
\text { preferred } \\
\text { fuelwood/fodder } \\
\text { species } \\
\text { * Reduction in } \\
\text { availability of } \\
\text { medicinal herbs and } \\
\text { other non-timber } \\
\text { forest products } \\
\text { (NTFPs) }\end{array}$ & $\begin{array}{l}* \text { Reduced clean water } \\
\text { availability in surrounding } \\
\text { forests } \\
\text { * Reduced water availability } \\
\text { for small-scale irrigation } \\
\text { * Lowered milk production } \\
\text { from cattle due to low- } \\
\text { quality fodder } \\
\text { * Increasing need to buy } \\
\text { fuel from market }\end{array}$ & $\begin{array}{l}* \text { While men are primarily } \\
\text { responsible for earning } \\
\text { wage-based income, the } \\
\text { collection of natural } \\
\text { resources (water, NTFP, } \\
\text { fodder, and fuelwood) is } \\
\text { primarily conducted by } \\
\text { women and children } \\
\text { * More time and energy is } \\
\text { required from women to } \\
\text { acquire natural resources } \\
\text { required for domestic } \\
\text { consumption and } \\
\text { livelihood requirements } \\
\text { * Women have to travel } \\
\text { farther away to find } \\
\text { resources, as diminishing } \\
\text { supplies are not being } \\
\text { replenished at past rates } \\
\text { * Increased labor demands } \\
\text { for women }\end{array}$ & $\begin{array}{l}\text { * Gender-based division of labor pattern holds } \\
\text { both in Garhwali and Bhotiya households (not } \\
\text { observed as differentiated by ethnicity) } \\
\text { * While women are responsible for NTFP } \\
\text { collection in both poor and non-poor } \\
\text { households, women of poorer households are } \\
\text { more dependent upon NTFPs as they lack } \\
\text { income to purchase other forms of fuels, fodder }\end{array}$ \\
\hline
\end{tabular}

Figure 2. Climate change indicators and impacts for NDBR women. 


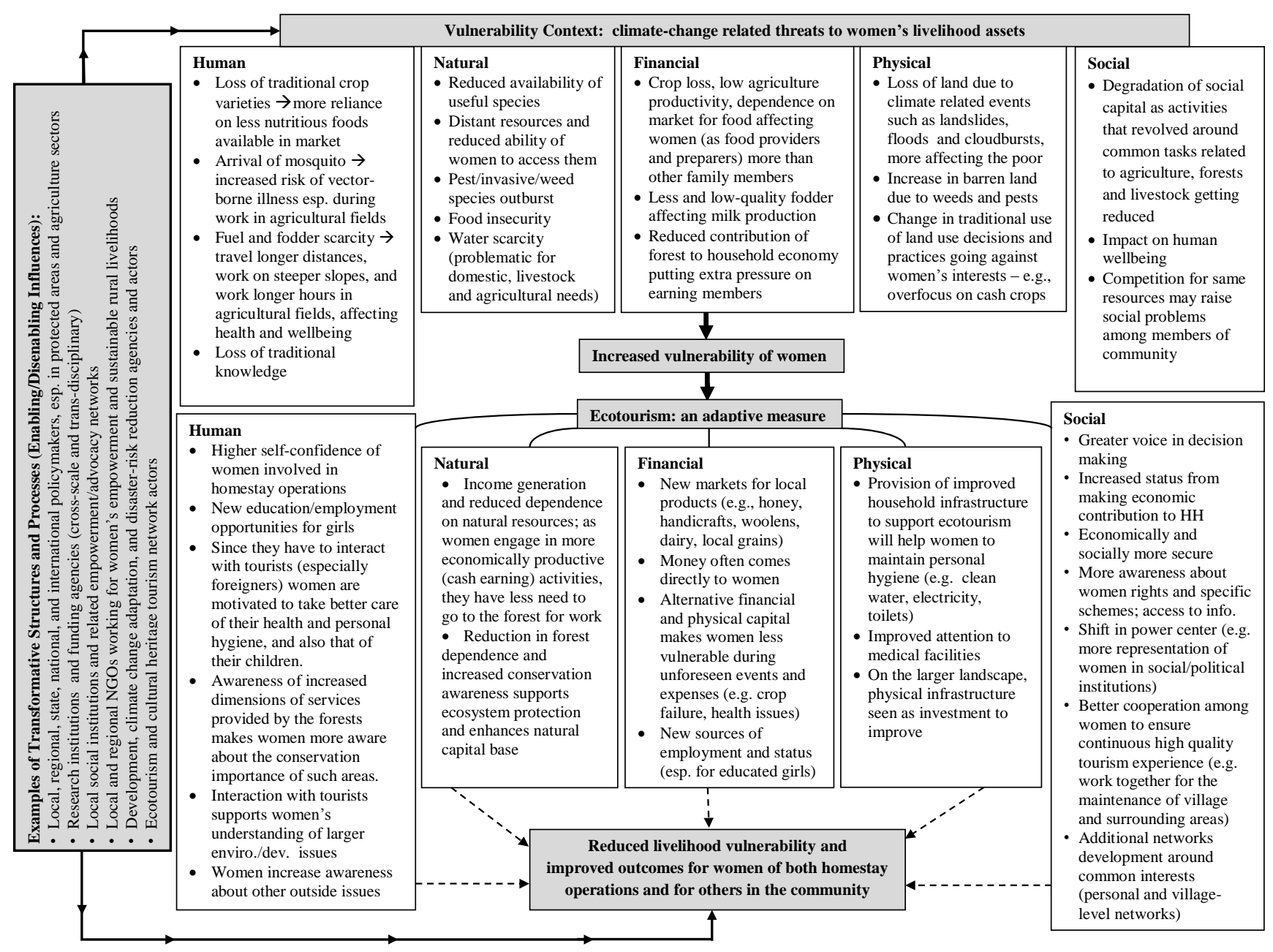

Figure 3. Application of sustainable livelihoods (SL) model.

forests. The lack of established (or properly functioning) village-based institutions where women can gather to discuss such village-level problems and work cooperatively to address them (e.g., traditional women-only institutions such as Mahila Mangal Dal) adds to the impact of the loss of important yet time-bound social spaces.

\subsection{Gender and ecotourism in the NDBR}

With the above discussion as context, in this section we apply the SL framework to the case of ecotourism in the NDBR. In addition to summarizing reported climate-related threats in terms of livelihood assets for women, Fig. 3 also illustrates how ecotourism has the ability to strengthen specific types of assets. These examples demonstrate the links between gender, climate change, and potential for increased adaptive capacity of communities through livelihood diversification. Following the SL framework, we have identified site-specific examples of human (e.g., education, knowledge, cultural practices), social (e.g., networks, arenas of status and/or power), natural (e.g., environmental resources), physical (e.g., infrastructure) and financial (e.g., income, wealth, land, livestock) assets.

Our observations in NDBR communities experimenting with ecotourism suggest improvements of key livelihood assets for women in participant-networked households, particularly with regard to development of human, social, and financial capital (areas that are often weaker for NDBR women as a group, as shown earlier in Table 1). In the households that have homestay facilities, for example, women reported that they benefitted from the opportunities to interact with the tourists afforded through their home-based activities such as cooking, cleaning, and creation of a welcoming space for guests. The resulting cultural interaction and mutual exchange of ideas led to the women feeling that they were now more aware of conservation and development issues, as well as feeling more self-aware in the areas of personal selfdevelopment, such as increased attention to self-care (personal hygiene, appearance) and knowledge of the surrounding areas. We also observed that while wealth largely deter- 
mined which households were able to directly participate in the homestay offering, the wider homestay economy carried social benefits that were distributed more broadly through multiplier effects in the villages. For example, those unable to host tourists still directly benefitted from development of public social spaces (village paths, tea stalls, etc.) where tourists and villagers could interact spontaneously beyond the homestay sites. In this way, the village itself plays a key part in its role as the larger host. Similarly, neighbors of homestay operators benefitted from interactions and insights achieved through informal visits. Through participation in less formalized social networks created and facilitated by the homestay model, women also cooperated more with each other and earned respect as a group through recognition of their key role in raising cash income for their families.

Greater financial resources at both village and household level have also translated into assets development for women, as personal investments into village facilities for the comfort of tourists (such as preparing time-consuming written applications for improvement of electrical grid and sanitation infrastructure) contribute to strengthening of physical capital assets across wealth categories. Village- and household-level improvements such as increasing the availability of clean water and expansion of toilet facilities promote women's assets by addressing sanitation and hygiene issues that disproportionately negatively impact women and children. In addition, homestay providers reported that a diversified income base associated with ecotourism led to less reliance on natural resource extraction in the nearby forests, due to practical reason of the extractors being gainfully employed. A reduction in women's forest-based labor for domestic fuel, water, and fodder collection opens up opportunities for women and their daughters to strengthen their human capital assets (e.g., self-care outcomes, education, job-skills development). However, even for households with sufficient funds to purchase fuel and/or fodder, women continue to meet domestic labor demands that include forest based resource collection. (Reasons include house location and relative proximity to transportation links (remoteness), cultural traditions associated with use of the chullah (cooking fire) and the need for warmth and comfort associated with wood-fueled fires in winter.)

Finally, we informally observed that in families which were getting regular tourists for their homestays, there was less need for long-term male migration. We can tentatively suggest that successful ecotourism operations may thus promote family integrity (human capital) through reduction of long-term male out-migration and promotion of a more integrated and cooperative model of income generation. Compared to the standing model of labor participation in the regional tourist industry (in which benefits accrue to families primarily through the contributions of male members working as porters, guides, cooks, and drivers), homestays represented a more inclusive model where both the women and men work together. Although the tasks are still more or less defined and implemented along lines of gender, the overall approach is a visibly complementary one (i.e., as compared to the earlier version where both worked on different activities and there was little overlap between their work, and in which women's domestic labor was not economically valued). In other words, in the ecotourism homestay households we visited, women and men were both positioned to be valued contributors to a larger, cooperatively based productive economic and domestic system.

\section{Discussion}

This paper is devoted to the illustration of links between gender and climate change, with a particular focus on women's differentiated experiences and assets needed to strengthen adaptive capacities. We have offered details from regional ecotourism experiences to suggest ways that livelihood assets can be strengthened, as part of a larger climate adaptation approach that employs a differentiated framework as its basis. We have shown that women experience genderdifferentiated outcomes related to climate change, and that these outcomes relate closely to critical livelihood assets required for sustainable and equitable development. Our experiences in the field suggest that gender-based impacts of climate change cut across social categories such as ethnicity and caste - particularly for women whose households are dependent on seasonal agriculture - due to a gender-based division of labor that is not (as we have so far observed) specific to these larger social and economic categories. Income, migration status, and household size do however appear to be crucial aspects for sustainable livelihood development, and are related directly to household assets and overall capacities.

The climate change impacts we have reported here for NDBR are consistent with women's climate change experiences emerging in other parts of the Himalayas, for example elsewhere in Uttarakhand (Negi et al., 2010), in Himachal Pradesh (Kapoor, 2011), and in the mountains of Nepal (Leduc et al., 2008 and Leduc, 2009; see also Eriksson et al., 2008 and Gentle and Maraseni, 2012, for similar reports about climate change impacts to women's health in Nepal). As at NDBR, views from the ground in these other locations show that gendered labor practices and other gendered norms strongly shape women's knowledge and experiences with climate change. As such, women's knowledge and prioritizations for action need to be made central in broader discussions of adaption. However, additional and larger-scale research is needed to generate the comparable data sets that will be required for differentiated action plans. We believe that in seeking women's participation in such studies, as attempted here, externally supported adaptation and/or mitigation planning can more closely reflect their priorities and thus be supported more effectively. Further work should continue inquiry of the role of difference within gender groups. If re- 
gional infrastructural and economic development resources are going to come to residents in the name of adaptation and mitigation to the impacts of climate change, it should happen in a way that reflects relevant patterns of differentiated knowledge and impacts. Investing in adaptive capacity of communities in this manner thus also represents a key opportunity to invest in and promote women's empowerment, a goal whose achievement is widely held as a prerequisite for sustainable development (e.g., as suggested by the Millennium Development Goals).

This study of the NDBR also suggests that household responses to crop failure and decreased agricultural yields are constrained in a range of ways that make it particularly difficult for poor families to enhance or diversify their income sources. For women in poor families, however, the hardship is compounded. Women from cash-poor households, for example, do not have the option of purchasing fuelwood or fodder; thus, the risks and labor costs that women in our study reported as inherent to their work increases in the absence of alternative assets. Similarly, in the face of recurring climateinduced crop failures or poor yields, switching from agriculture to animal husbandry may be a viable strategy for generation of cash but could also ultimately undermine household nutrition and food security (overseen by women). As others have also observed, Himalayan women are typically "the last to eat and also eat the least" (Negi et al., 2010: 75).

Our research also demonstrates that ecotourism related to NDBR, as an experiment in livelihood diversification, is slowly changing the assets profiles of participating women. On the surface, it would seem that the benefits of this arrangement accrue inequitably in terms of gender: men strengthen their financial and personal assets, status, and role as breadwinners through participation in the formal and monetized ecotourism industry; meanwhile, women are typically involved only in unpaid, traditionally low-status domestic tasks such as preparing food, cleaning, and fetching of fuelwood and other natural resources. However, our research shows that women's assets are being strengthened, albeit in different domains from men. Increases in women's cooperative arrangements associated with strengthened social capital are particularly important, however, because they may ultimately support emergence of new cooperative institutions (e.g., new ecotourism and/or ecodevelopment committees) or enable meaningful changes in existing ones (e.g., villagelevel governance bodies, Van Panchayat - forest council, revival of traditional groups such as Mahila Mangal Dal women's group - or yuva mandal - youth group). Rather than remaining silent spectators in formal institutional settings or limiting their participation to simply adding their names to member attendance rosters, strengthened human and social capital assets would help women have more of a say in decision-making regarding their economic activities as well as about management and use of the natural resource base.
Involvement of women in ecotourism activities at NDBR has also benefitted the wider community, by broadening the spectrum of tourism beneficiaries and expanding the skill sets now held by people engaged in related activities. It is also setting positive examples for others and modeling the potential for change to occur through cooperation and challenging of previously held beliefs about obstacles and limitations. In the face of increasing vulnerability of traditional agriculturally based livelihoods and pressures for men to out-migrate, we believe that under the right conditions, ecotourism has the potential to become an important part of a larger adaptation strategy that strengthens families' adaptive capacity and resilience of livelihoods for the mountain regions. These early findings resonate with longer-term experiments elsewhere in the region. For example, a larger-scale formal homestay program organized and run since 2002 by the Sarmoli village Van Panchayat (forest council) in the Pithoragarh district of Uttarakhand has been linked to both women's empowerment and improvement of the local village economy (Macek, 2012). As in our study, Macek (2012) reports that in their role as hosts, Sarmoli women demonstrate leadership through cooking, interaction with guests, and education of guests about their lives and lifestyles; Macek further notes that for some families, the homestay has positioned women of the household as the primary income earner and is helping villagers to overcome barriers posed by tradition.

At the same time, participation in homestay-based ecotourism is shaped strongly by wealth and other householdlevel livelihood assets. A recent study of NDBR homestay operators found that related home investments averaged a total of INR 172417 (Von Hedemann, 2010), a figure nearly twice the amount of the reported average annual incomes of households in our study area. Because of inter-group differences, the risk of widening gaps between strongly and weakly endowed households is therefore a key concern. As previously discussed, those most negatively affected by climate change are likely to possess fewer livelihood assets than wealthier (or more educated, effectively networked, or mobile) counterparts who are better positioned to be able to cope with the stresses of climate change. Such counterparts are also more likely to directly benefit from investment in ecotourism and hosting tourists. For this to be a strategy that accrues benefits in an equitable, communitywide manner, capture of benefits by elites must be anticipated and avoided through participatory approaches to planning and benefit sharing that recognize and develop capacity of all potential beneficiaries. Otherwise, homestays risk spreading environmental and cultural costs over the entire village, whilst only those wealthy enough to invest reap the lion's share of benefits. In addition, while gender concerns remain important as an entry point into understanding distribution of benefits at a finer scale than the household, we note that access to benefits will also be linked to other factors in equally critical ways. Though we were not able to focus on age in the present study, our previous studies of ecodevelop- 
ment efforts (including ecotourism) at a range of Himalayan sites suggested that age and gender together shaped benefit flows in important ways (Badola et al., 2014b). Similarly, a study of caste interactions and patronage ties between tenant farmers and landholders in the mountains of Nepal found that although climate change adaptation options were shaped by caste, they simultaneously reinforced existing and unequal gender norms related to division of labor and opportunities for income generation (Onta and Resurreccion, 2011).

Effective use of assets-based models will remain an important tool for better understanding the relative strengths, weaknesses, constraints, and opportunities facing individuals, households, or communities in the context of climate change. As suggested by our case study, ecotourism can contribute to the promotion of non-consumptive use of mountain resources and (under the right circumstances) can be an important tool for providing well-defined livelihood enhancement opportunities, but this is just one example of an alternative livelihood strategy. We do not wish to suggest that any one adaptation strategy will be a panacea, or that all NDBR communities or households should now invest in homestaybased ecotourism. Our goal in discussing the ecotourism experiences at NDBR is to demonstrate the value of bringing an assets-based approach to questions of adaptive capacity. Indeed, in other areas ecotourism has led to weakening of assets (Coria and Calfucura, 2012) or led to concerns of cultural and social erosion (Scheyvens, 1999). Tourism of any type also carries its own footprint. Increased instances of littering of non-biodegradable trash, improper waste disposal and contamination of water sources along trekking routes are existing impacts at the NDBR itself (Maikhuri et al., 2001). Homestay-based accommodation also poses the risk of dispersing such impacts over the host villages as well, if it is not carefully anticipated. In addition, the needs of homestay operators for additional fuel, food, and water will all contribute to local human and environmental costs.

\subsection{Suggestions for action and further research}

Climate change obviously poses myriad challenges, which we believe will increasingly demand a team-based research approach that brings together climate scientists, policy and systems modelers, and social scientists. The range of observed physical changes already demand, as well, that as researchers we work collaboratively to conceptualize the problem at all scales - global, national, regional, and local as well as intra-community and inter-community. It is perhaps from this latter perspective that differentiated impacts, as seen through a lens of gender (in conjunction with other stratifying categories), can best help to inform an applied research agenda. Our examples illustrate that because the impacts and burdens of climate change are clearly differentiated, adaptation strategies will need to be conceived in ways that are both gender sensitive in the short term and, ideally, socially transformative in the long term (Fig. 4). In addition to techni- cal interventions aimed at reducing differentiated impacts of climate change, responsive institutional and research-related practices such as gender mainstreaming and gender budgeting (e.g., for data analysis, project assessment) will be key to advancing the paradigm shift from gender blindness to socially transformative visions of gender justice and equity. However, as shown in the SL model itself (Figs. 1 and 3), such changes cannot occur without enabling changes in the surrounding institutional, economic, and cultural landscapes. This has implications for the research, policymaking, and financing landscapes as well as for the communities we aim to support through our endeavors.

In the spirit of speaking across the disciplinary boundaries represented by this issue of $E S D$, before closing this paper we offer some questions and ideas for further study. We hope that this discussion stimulates readers to ask themselves how their own inquiries and methodological approaches can add to this starting list. First, the following are areas for consideration by Himalayan climate scientists and policy modelers: how can models of changing monsoon patterns be improved to reflect possible implications for the food crops preferred by women cultivators, in comparison to cash crops promoted by state-based or corporate and/or multinational agricultural extension agents? Knowing that certain groups of individuals in the high-altitude Himalayas (farmers, elderly residents, and trekking guides, for example) possess tremendous knowledge about agro-ecological, glacial extent, and forest-based biodiversity changes, how can models of environmental change more directly take into account gendered and locally produced knowledge? In what ways can predictive models better reflect the hazards associated with smallscale disasters (localized landslides or weather-related crop failures, for example) for different groups - or provide finerscale data about shifting monsoons, wind patterns, and land cover changes, as suggested by IPCC working group members (IPCC-WG2, 2014)? Can spatial models of flood hazard for the region incorporate practices from participatory GIS to intentionally reflect the location of gender-based and activist network hubs, as researchers in the area of disaster studies elsewhere have suggested (e.g., Leduc et al., 2008; Knight et al., 2012) as a way to better support members of transgendered communities? ${ }^{3}$

Existing lines of climate change and livelihood research undertaken by social scientists and policy and/or systems

\footnotetext{
${ }^{3}$ Recent work in the field of gender and disasters has shown that relief services and support are frequently gender-segregated, functionally excluding transgender communities such as hijras in India, warias of Indonesia, baklas in the Philippines, and LGBTQI and/or genderqueer communities in the USA (Balgos et al., 2012; Dominey-Howes et. al., 2014; Knight et al., 2012). These genderfluid communities are, at the same time, connected through networks that can be important resources for disaster-related information, services, and support. In breaking away from binary analytical models, such research reflects important new directions and paradigms for gender and climate change studies.
} 
Climate Change Adaptation Practices - Gender Intervention Typology*

Classification

\section{Gender-Blind}

\& Gender-Neutral

Gender-Sensitive

\& Gender-Responsive

Gender-Transformative \& Gender-Justice

\section{Description}

Interventions essentially ignore gender difference and caste/class economic inequality. They appear neutral but are unintentionally biased in favor of men. Interventions reinforce existing gender- and caste/class economic inequalities. Status-quo gender relations and attendant inequities are accepted and/or reinforced.

Interventions recognize and attempt to mitigate the impacts of existing gender inequalities, particularly for women/girls; these efforts may however still fall short if they do not take into account caste/class-based differences. Policies promote and protect women's/girl's self-determination and rights, and create spaces for men to benefit from women's empowerment as part of the process. Goals are linked to gender mainstreaming in institutions, but top-down approaches may still drive policy/practice.

Interventions aim to transform gender relations to promote gender equity across scales (i.e., between and within gender groups), and which recognize the intersections of gender and other forms of difference. Institutional gender mainstreaming efforts are complete and bottom-up approaches and reinforce gender equality. Norms, policies, and practices lead to ideological and structural changes in gender-based power relations at all levels.

\section{Examples of Practice}

Resource management schemes for participation/benefit-sharing are targeted to registered heads of household (usually de jure men, even if de facto women). Agricultural extension workers engaging with men to promote pest-resistant cash crop seeds instead of working with women farmers to support cultivation of climate-appropriate traditional food/fodder crops for consumption at local scales. Market-based approaches to agro-forestry that seek to develop carbon credits, rather than livelihood needs for timber and usufruct rights for minor forest products which benefit local communities (upon which women, especially poor women, depend intensively).

Eliciting and supporting women's existing/stated priorities for climate change adaptation activities. Participatory approaches to climate change risk mitigation and adaptation planning. Genderbudgeting in development project planning and practice. Genderdisaggregation of all data and policy impact assessments. Energysaving initiatives and technologies designed to reduce women's drudgery and labor in fuelwood collection. Mandated reservation quotas for women in decision-making bodies at all levels. Creation of new institutions and networks that promote strengthening of gendered assets/capability, despite gender-based divisions of labor which may remain central to mountain livelihood strategies.

Total elimination of societal acceptance of discrimination and violence committed as a result of gender inequality. No group suffers disproportionately negative impacts of climate change or hazard due to gender. Recognition of the fluidity and changeable nature of gender identities and gender relations, particularly for disaster risk reduction and response. (Note: Recent policies such as India's creation of three census categories are encouraging in this context and will enable gender-disaggregation of data, but transformation to a gender-justice paradigm is not yet complete.)

* Adapted from Kapoor, 2011

Figure 4. Climate change adaptation practices - gender intervention typology.

modelers can also be reframed and enhanced through a teambased approach that reflects a commitment to socially transformative research and which operates across scales. For example, through what pathways does agro-ecological and climate-related information flow throughout a community and how, if at all, are they gendered? Are there groups of people who are not captured in these webs, and if so, how can policy interventions reach them more effectively? For ecotourism to be a socially as well as environmentally sustainable alternative livelihood, can models of cost and benefit more explicitly take into account the value of women's largely unremunerative labor? How can dominant livelihood choices, such as migration, be better represented in models of climate change response, to better understand the drivers underlying these decisions as well as the contribution to adaptive capacity for persons of all genders? ${ }^{4}$ Bear-

\footnotetext{
${ }^{4}$ For example, work in the field of masculinity studies (e.g., Cornwall et. al., 2011) pushes researchers interested in gender and climate change to centralize men's experiences, in seeking to bet-
}

ing in mind that land tenure and land use practices are highly gendered and class- and/or caste-differentiated in the Indian Himalayas, how will sustainable energy infrastructure or land-use projects targeted for the region (such as hydroelectric power plants) be implemented in ways that strengthen, rather than undermine, differentially held assets? Under what tenurial and natural resource management regimes, and at what scales, will national and regional carbon sequestration goals most equitably be achieved?

Finally, social scientists with expertise in fine-scale analysis can play an especially key role in generating the ethnographic and methodological perspectives required to adequately analyze the complexities revealed by individual experiences. What information do different groups of people need in order to more effectively plan and make choices

ter understand the lived experiences of fathers, brothers, and sons who leave their families in climate-stressed areas in order to serve as remittance providers. See also previous note regarding studies of disasters and LGBTQI communities. 
about adaptive responses? Gender and development scholars have long called for economic growth and income-based models, disaster response plans, alternative livelihood strategy designs, integrated conservation-development initiatives, and other critical resources for sustainable development planning to be implemented with reliable, gender-disaggregated data sets (and ideally operate at even finer and non-binary scales). Yet outside of small-scale, time- and labor-intensive qualitative case studies or broad-brush quantitative analyses of difference achieved through large-scale surveys, it is difficult to envision how sufficiently detailed knowledge about differentiated vulnerabilities, strengths, and needs in the region will be achieved at the scales and speed required. One must ask, in an area with such topographic and cultural complexity, how can logistical, financial, and methodological limitations be overcome so that best practices can be more clearly identified and communicated? These are some of the questions that drive our own continued research.

There is clearly still so much work to be done, and a need for research on the specific outcomes that climate change is likely to bring to Himalayan communities. Ultimately, we would urge that researchers of climate change impacts employ frameworks that include differentiated vulnerabilities, wherever possible - to analyze not only vulnerabilities obviously shaped by poverty, but also by gender-differentiated vulnerabilities in all their variants. It is with this foundation that we will be able to move more effectively toward adaptation and mitigation strategies that build rather than weaken the livelihood assets not only for women, but for all facing risk.

\section{Conclusion}

The integration of frameworks based on differentiated vulnerabilities offers an opportunity for climate change researchers and policymakers to contribute to the ensured viability of the mountain communities by (a) avoiding the trap of gender-blindness in research, policy, and intervention designs, and (b) seeking to develop and strengthen livelihood assets of vulnerable populations, while (c) simultaneously working to promote the transformation of enabling structures. In the Indian Himalayas, we believe that this requires recognition of the largely unacknowledged yet productive livelihood contributions of mountain women, and a prioritization of women's assets development to help promote adaptive capacity at a range of scales. Research and policy collaboration with local institutions will also be important to expanding forms of social capital and networks of support, in the face of livelihood uncertainty and ecological change. For researchers, increased dissemination of climate-related information and relevant research findings to all affected communities can be a related goal. Information supports choice, and choice is required for empowerment and action. By investing our time and inquiries in ways that integrate gendered per- spectives into larger questions about differentiated vulnerabilities, adaptive capacity, and equity, we can help to provide the support required for Himalayan residents to envision and develop new sources of strength themselves.

Acknowledgements. We wish to thank the editors of this special issue, especially Giovanna Gioli and Valerio Lucarini, for the opportunity to share our perspectives and for their support of this paper. Constructive and insightful feedback on an earlier version of this paper was generously provided by fellow KlimaCampus workshop participant M. Hobley and an anonymous reviewer. We each also gratefully acknowledge funding from our home institutions for supporting our fieldwork in the NDBR. Special thanks are additionally extended to Upma Manral and Pariva Dobriyal for their research assistance contributions. Finally, we express our gratitude and appreciation for the many NDBR residents who graciously invited us into their homes and took the time to answer our many questions.

Edited by: V. Lucarini

\section{References}

Adger, W. N., Barnett, J., Brown, K., Marshall, N., and O'Brien, K.: Cultural dimensions of climate change impacts and adaptation, Nat. Clim. Change, 3, 112-117, 2013.

Adhikari, J. and Hobley, M.: Everyone is Leaving - Who Will Sow Our Fields? Effects of migration from Khotang district to the Gulf and Malaysia, Kathmandu, Swiss Agency for Development and Cooperation (SDC) and HELVETAS Swiss Intercooperation, 2011.

Agarwal, B.: The gender and environment debate: lessons from India, Fem. Stud., 119-158, 1992.

Aguilar, L.: Gender and Climate Change: An Introduction: Establishing the Linkages Between Gender and Climate Change Adaptation and Mitigation, in: Gender and Climate Change: An Introduction, 173-193, 2010.

Alagan, R. and Aladuwaka, S.: Gender mapping in post-disaster recovery: lessons from Sri Lanka's tsunami, in: Global Perspectives on Gender and Space, edited by: Oberhauser, A. and Johnston-Anumonwo, I., Routledge, New York, 181-199, 2014.

Alston, M. and Whittenbury, K.: Research, Action and Policy: Addressing the Gendered Impacts of Climate Change: Addressing the Gendered Impacts of Climate Change, Springer, New York, 2012.

Arora-Jonsson, S.: Virtue and Vulnerability: Discourses on women, gender and climate change, Global Environ. Change, 21, 744751, 2011.

Badola, R., Hussain, S. A., Dobriyal, P., and Barthwal, S. C.: An integrated approach to reduce the vulnerability of local community to environmental degradation in the Western Himalayas, India, Final Study Report, Dehradun, India: Wildlife Institute of India, 2014a.

Badola, R., Ogra, M. V., and Barthwal, S. C.: Ecodevelopment, Gender, and Empowerment: Perspectives from India's Protected Area Communities, in Gender, Development and Transnational Feminism: Engaging Feminism and Development, edited by: 
Oberhauser, A. and Johnston-Anumonwo, I., Routledge, New York, 200-233, 2014b.

Balgos, B., Gaillard, J. C., and Sanz, K.: The Warias of Indonesia in disaster risk reduction: The case of the 2010 Mt Merapi eruption, Gender Dev., 20, 337-348, 2012.

Blaikie, P. and Brookfield, H.: Land Degradation and Society, New York, Routledge, 1987.

Brody, J., Demetriades, J., and Esplen, E.: Mapping the Linkages. A Scoping Study on Knowledge and Gaps, available at: http: //siteresources.worldbank.org/EXTSOCIALDEVELOPMENT/ Resources/DFID_Gender_Climate_Change.pdf (last access: 10 September 2014), 2008.

Coria, J. and Calfucura E.: Ecotourism and the development of indigenous communities: The good, the bad, and the ugly, Ecol. Econ., 72, 47-55, 2012.

Cornwall, A., Edstrom, J., and Grieg, A. (Eds.): Men in Development: Politicizing Masculinities, London/New York, Zed/Palgrave Macmillan, 2011.

Dankelman, I. (Ed.): Gender and Climate Change: An Introduction, Earthscan, Washington, DC, 2010.

David, E. and Enarson, E. (Eds.): The Women of Katrina: How Gender, Race and Class Matter in an American disaster, Vanderbilt University Press, Nashville, Tennessee, 2012.

Demetriades, J. and Esplen, E.: The Gender Dimensions of Poverty and Climate Change Adaption, in: Social Dimensions of Climate Change: Equity and Vulnerability in a Warming World, edited by: Mearns, R. and Norton, A., The World Bank, Washington D.C., 133-144, 2010.

Denton, F.: Climate Change Vulnerability, Impacts, and Adaptation: Why Does Gender Matter?, Gender Dev., 10, 10-20, 2002.

Denton, F.: Gender and Climate Change: Giving the "Latecomer" a Head Start, IDS Bulletin, 35, 42-49, 2004.

Department for International Development (DFID): Sustainable Livelihoods Guidance Sheet, available at: www.eldis.org/vfile/ upload/1/document/0901/section2.pdf (last access: 10 September 2014), 1999.

Dominey-Howes, D., Gorman-Murray, A., and McKinnon, S.: Queering Disasters: on the need to account for LGBTI experiences in natural disaster contexts, Gen. Place Cult., 21, 905-918, 2014.

Ellis, R.: The Determinants of Rural Livelihood Diversification in Developing countries, J. Agr. Econ., 51, 289-302, 2000.

Enarson, E. and Chakrabati, B. G. (Eds.): Women, Gender and Disaster: Global Issues and Initiatives, Sage Publications, New Delhi, India, 2009.

Enarson, E. and Morrow, B.: The Gendered Terrain of Disaster: Through Women's Eyes, Praeger, Miami, 1998.

Eriksson, M., Fang, J., and Dekens, J.: How does climate change affect human health in the Hindu Kush-Himalaya region?, Reg. Health Forum, 12, 11-15, 2008.

FAO - Food and Agriculture Organization of the United Nations: Livelihoods, Poverty, and Institutions, in: Institutions for Rural Development Series, Rapid Guide for Missions: Analyzing Local Institutions and Livelihoods, Rome, FAO, available at: http: //www.fao.org/docrep/008/a0273e/a0273e04.htm\#bm04 (last access: 10 September 2014), 2005.

Fussel, H. and Klein, R.: Climate change vulnerability assessments: An evolution of conceptual thinking, Clim. Change, 75, 301$329,2006$.
Gender and Disaster Network (GDN): Gender and disaster knowledgebase, last access: 10 September 2014, available at: http: //www.gdnonline.org/knowledgebase.php, 2014.

Gentle, P. and Maraseni, T.: Climate change, poverty and livelihoods: adaptation practices by rural mountain communities in Nepal, Environ. Sci. Pol., 21, 24-34, 2012.

Giri, K. and Darnhofer, I.: Outmigrating men: A window of opportunity for women's participation in community forestry?, Scand. J. For. Res., 25, 55-61, 2010.

Government of India (GOI), 2011 Census of India, Population enumeration data, last access: 10 Sept 2014, available at: http://www.censusindia.gov.in/2011census/population enumeration.aspx, 2011.

Government of India (GOI), Census 2001, Provisional population totals 2001, last access: 10 Sept 2014, available at: http: //kokrajhar.gov.in/census.htm\#i5, 2002.

Green, M.: Nature Reserves of the Himalayas and the Mountains of Central Asia, Oxford University Press, Oxford, 1993.

Gusain, R. and Datt, G.: Relief efforts in flood-hit Uttarakhand break down. Daily Mail Online- India, last access: 10 September 2014, available at: http://www.dailymail.co.uk/indiahome/ indianews/article-2351994, 2013.

Hemmati, M. and Röhr, U.: Engendering the climate-change negotiations: experiences, challenges, and steps forward, Gender Dev., 17, 19-32, 2009.

Huang, W., Kan, H., and Kovats, S.: The impact of the 2003 heat wave on mortality in Shanghai, China, Sci. Total Environ., 408, 2418-2420, 2010.

Intergovernmental Panel on Climate Change (IPCC-WG2), Report by Working Group II: Impacts, Adaptation and Vulnerability, available at: http://www.ipcc.ch/ipccreports/tar/wg2/index.php? idp=674 (last access: 10 September 2014), 2014.

Ives, J. D. and Messerli, B.: The Himalayan Dilemma: Reconciling Development and Conservation, Routledge, London, 1989.

Kala, C. and Maikhuri, R.: Mitigating people-park conflicts on resource use through ecotourism: A case of the Nanda Devi Biosphere Reserve, Indian Himalaya. J. Mt. Sci., 8, 87-95, 2011.

Kapoor, A.: Engendering the climate for change: Policies and practices for gender-just adaptation, Alternative Futures and Heinrich Böll Foundation, New Delhi, India, 2011.

Khacher, L.: The Nanda Devi Sanctuary, J. Bonbay Nat. Hist. Soc., 3, 38-49, 1978.

Knight, K., Gaillard, J. C., and Sanz, K.: Gendering the MDGs beyond 2015: understanding needs and capacities of LGBTI persons in disasters and emergencies, Global Consultation on Addressing Inequalities, UN Women and UNICEF, , available at: http://www.worldwewant2015.org/node/283239 (last access: 10 September 2014), 2012.

Lambrou, Y. and Piana, G.: Gender: The missing component of the response to climate change, Food and Agriculture Organization of the United Nations (FAO), Rome, 2006.

Leduc, B., Shrestha, A., and Bhattarai, B.: Gender and Climate Change in the Hindu Kush Himalayas of Nepal, Report prepared for the WEDO Gender and Climate Change Workshop, Dakar, Senegal, 2-3 June, available at: http://www.wedo.org/ wp-content/uploads/nepalcasestudy.pdf (last access: 10 September 2014), 2008. 
Leduc, B.: Gender and Climate Change in the Himalayas (ICIMOD discussion paper), available at: http://www.icimod.org/resource/ 455 (last access: 10 September 2011), 2009.

MacGregor, S.: Gender and climate change: from impacts to discourses, J. Indian Ocean Reg., 6, 223-238, 2010.

Macek, I: Homestays as Livelihood Strategies in Rural Economies: The case of Johar Valley, Uttarakhand, India, PhD diss., University of Washington, available at: https://dlib.lib.washington.edu/ researchworks/handle/1773/21845 (last access: 4 Februar 2014), 2012.

Maikhuri, R. K., Nautiyal, S., Rao, K. S., and Saxena, K. G: Conservation policy-people conflicts: a case study from Nanda Devi Biosphere Reserve (a world heritage site), India, Forest Pol. Econ., 2, 355-365, 2001.

Masika, R.: Gender, Development, and Climate Change, Oxford, OXFAM, 2002.

Mearns, R. and Norton, A. (Eds.): Social Dimensions of Climate Change: Equity and Vulnerability in a Warming World, World Bank, Washington, D.C., 2010.

Moser, C.: Gender planning in the Third World: meeting practical and strategic gender needs, World Dev., 17, 1799-1825, 1989.

Nanda Devi Biosphere Reserve (NDBR): Nanda Devi Biosphere Reserve Management Plan, Uttarakhand Forest Department, Joshimath, 2002.

Negi, B., Sogani, R., and Pandey, V.: Climate Change and Women's Voices From India, edited by: Dankelman I., Gender and Climate Change: An Introduction, Earthscan, Washington, DC, 2010.

Nelson, V., Meadows, K., Cannon, T., Morton, J., and Martin, A.: Uncertain predictions, invisible impacts, and the need to mainstream gender in climate change adaptations, Gender Dev., 10, 51-59, 2002.

Neumayer, E. and Plümper, T.: The Gendered Nature of Natural Disasters: The Impact of Catastrophic Events on the Gender Gap in Life Expectancy, 1981-2002, Ann. Assoc. Am. Geogr., 97, 551-566, 2007.

Onta, N. and Resurreccion, B.: The role of gender and caste in climate adaptation strategies in Nepal: emerging change and persistent inequalities in the far-western region, Mt. Res. Dev., 31, 351-356, 2011.

Pand, S.: Joshimath Children worst affected in Uttarakhand, available at: http://www.actionaidusa.org/india/2013/09/ joshimath-children-worst-affected-uttarakhand (last access: 10 September 2014), 2013.

Poumadère, M., Mays, C., Le Mer, S., and Blong, R.: The 2003 Heat wave in France: Dangerous Climate Change Here and Now, Risk Anal., 25, 1483-1494, 2005.

Rasul, G.: Food, water, and energy security in South Asia: A nexus perspective from the Hindu Kush Himalayan region, Environ. Sci. Policy, 39, 35-48, 2014.

Rocheleau, D., Thomas-Slayter, B., and Wangari, E. (Eds.): Feminist political ecology: Global issues and local experience, Routledge, New York, 1996.
Scheyvens, R.: Ecotourism and the empowerment of local communities, Tourism Manage., 20, 245-249, 1999

Scoones, I.: Sustainable Livelihoods: A Framework For Analysis, IDS Working Paper 72, available at: http: //opendocs.ids.ac.uk/opendocs/bitstream/handle/123456789/ 3390/Wp72.pdf?sequence $=1$ (last access: 10 September 2014), 1998.

Seager, J.: Death by degrees: Taking a feminist hard look at the $2^{\circ}$ climate policy. Kvinder, Køn \& Forskning, Women, Gender Res., 34, 11-21, 2009a.

Seager, J.: Atlas of Women in the World, 4th Edn., Penguin, New York, 2009b.

Seager, J.: Noticing Gender (or Not) in Disasters, in: The Women of Katrina: How Gender, Race, and Class Matter in an American Disaster, edited by: Enarson, E. and David, E., Vanderbilt University Press, Nashville, Tennessee, 2012.

Sultana, F.: Gendering Climate Change: Geographical Insights, Prof. Geogr., 6, 372-381, 2014.

Sweetman, C.: Climate changes and climate justice, Gender Dev., 17, 1-3, 2009.

Terry, G.: No climate without gender justice: an overview of the issues, Gender Dev., 17, 5-18, 2009.

United Nations (UN): UNFCCC: Copenhagen Accord, available at: https://unfccc.int/meetings/copenhagen_dec_2009/items/5262. php (last access: 10 September 2014), 2009.

United Nations (UN): UNFCCC Gender and Climate Change, available at: http://unfccc.int/gender_and_climate_change/items/ 7516.php (last access: 10 September 2014), 2014a.

United Nations (UN): UNFCCC: Gender and Climate Change: Connecting Climate and Gender, available at: http://unfccc.int/ gender_and_climate_change/items/7537.php\#connection (last access: 10 September 2014), 2014b.

United Nations Development Programme (UNDP): Gender and Climate Change, available at: http://www.undp.org/content/undp/ en/home/ourwork/environmentandenergy/strategic_themes/ climate_change/focus_areas/gender_and_climatechange/, 2014.

Von Hedemann, N.: An Assessment of Ecotourism and Local Economics in Nanda Devi Biosphere Reserve, India, Conference presentation at the Pathways to Success: Integrating Human Dimensions into Fish and Wildlife Management, Estes Park, Colorado, 27 September-1 October 2010.

Wisner, B., Blaikie, P. M., Cannon, T. and Davis, I.: At Risk: Natural Hazards, People's Vulnerability and Disasters, 2nd Edn., New York, Routledge, 2004.

World Bank: World Development Report 2012: Gender Equality and Development, last access: 10 September 2014, available at: http://go.worldbank.org/CQCTMSFI40, 2012.

World Health Organization (WHO), Gender, Climate Change, and Health, last access: 10 March 2015, available at: http://apps.who. int/iris/handle/10665/144781, 2014. 